\title{
5-HT IB Receptor-Mediated Serotoninergic Modulation of Methylphenidate-Induced Locomotor Activation in Rats
}

\author{
Janusz Borycz', Agustin Zapata', César Quiroz', Nora D Volkow ${ }^{1,2}$ and Sergi Ferré*,' \\ 'Department of Health and Human Services, National Institute on Drug Abuse, Intramural Research Program, National Institutes of Health, \\ Baltimore, MD, USA; ${ }^{2}$ Department of Health and Human Services, National Institute on Alcohol Abuse and Alcoholism, National Institutes \\ of Health, Bethesda, MD, USA
}

\begin{abstract}
Previous studies have shown that the dopamine (DA) uptake blocker methylphenidate, a psychostimulant widely used for the treatment of attention-deficit hyperactivity disorder (ADHD), prevents the neurotoxic effects of the highly abused DA releaser methamphetamine. However, there is a lack of information about the pharmacological interactions of these two drugs at the behavioral level. When systemically administered within an interval of $2 \mathrm{~h}$, previous administration of methylphenidate $(10 \mathrm{mg} / \mathrm{kg}$, intraperitoneal (i.p.)) did not modify locomotor activation induced by methamphetamine. On the other hand, previous administration of methamphetamine (I mg/kg, i.p.) markedly potentiated methylphenidate-induced motor activation. With in vivo microdialysis experiments, methamphetamine and methylphenidate were found to increase DA extracellular levels in the nucleus accumbens (NAs). Methamphetamine, but not methylphenidate, significantly increased the extracellular levels of serotonin (5-HT) in the NAs. Methamphetamine-induced 5-HT release remained significantly elevated for more than $2 \mathrm{~h}$ after its administration, suggesting that the increased 5 -HT could be responsible for the potentiation of methylphenidate-induced locomotor activation. In fact, previous administration of the 5-HT uptake blocker fluoxetine $(10 \mathrm{mg} / \mathrm{kg}$, i.p.) also potentiated the motor activation induced by methylphenidate. A selective 5-HT IB receptor antagonist (GR 55562; I mg/kg), but not a 5- $\mathrm{HT}_{2}$ receptor antagonist (ritanserin; $2 \mathrm{mg} / \mathrm{kg}$, i.p.), counteracted the effects of methamphetamine and fluoxetine on the motor activation induced by methylphenidate. Furthermore, a 5-HT IB receptor agonist (CP 94253; $1-10 \mathrm{mg} / \mathrm{kg}$, i.p.) strongly and dose-dependently potentiated methylphenidate-induced locomotor activation. The $5-\mathrm{HT}_{\mathrm{IB}}$ receptor-mediated modulation of methylphenidate-induced locomotor activation in rat could have implications for the treatment of ADHD.
\end{abstract}

Neuropsychopharmacology (2008) 33, 619-626; doi:I0.1038/sj.npp. I301445; published online 9 May 2007

Keywords: methylphenidate; methamphetamine; fluoxetine; dopamine; serotonin; 5-HT IB receptor

\section{INTRODUCTION}

Psychostimulants can be classified as 'dopamine (DA) uptake blockers' and 'DA releasers', according to their molecular mechanism of action. DA uptake blockers, such as cocaine, methylphenidate, or GBR 12909 , bind to and inhibit DA transporter (DAT) function (Torres et al, 2003; Elliott and Beveridge, 2005). DA releasers, such as amphetamine or methamphetamine, also bind to DAT and they enhance neurotransmitter release by reversing DA transport (Elliott and Beveridge, 2005; Sulzer et al, 2005). It has been shown that DA uptake blockers can also block reverse transport, thereby antagonizing the increase in extracellular DA induced by a DA releaser (Zetterstrom

\footnotetext{
*Correspondence: Dr S Ferré, Department of Health and Human Services, National Institute on Drug Abuse, Intramural Research Program, National Institutes of Health, 5500 Nathan Shock Drive, PO Box 5180, Baltimore, MD 21224, USA, Tel: + I 410550 1586, Fax: + I 410550 1648, E-mail: sferre@intra.nida.nih.gov Received 29 October 2006; revised 5 April 2007; accepted 6 April 2007
}

et al, 1988; Hurd and Ungerstedt, 1989; Villemagne et al, 1999; Baumann et al, 2002). Furthermore, DA uptake blockers and DA releasers exert differential effects on vesicular monoamine transporter-2 (VMAT-2) function, which seems to depend on a redistribution of VMAT-2 to different cellular compartments, and it has been suggested that the neurotoxic effects of amphetamines are related to their effects on VMAT-2 trafficking (Sandoval et al, 2003; Hanson et al, 2004).

The above-mentioned experimental findings suggest that DA uptake blockers, which have been suggested to have low abuse liability, such as methylphenidate or GBR 12909 (Chait, 1994; Skjoldager et al, 1993; Preti, 2000; Volkow and Swanson, 2003), could be used to counteract the addictive and neurotoxic effects of highly abused DA releasers, such as methamphetamine (Barr et al, 2006). In fact, methylphenidate has been shown to counteract the effects of high-dose methamphetamine administration on VMAT-2 function and persistent DA deficits in rats (Sandoval et al, 2003; Hanson et al, 2004). However, to our knowledge, there is no information about the pharmacological interactions of 
methylphenidate with methamphetamine at the behavioral level. Furthermore, the few results that have been reported about the influence of GBR 12909 on the behavioral effects of methamphetamine seem to be opposite to the expected effects. Thus, in drug discrimination experiments, GBR 12909 potentiated the effects of methamphetamine in rats and monkeys (Holtzman, 2001; Czoty et al, 2004).

In the present study, we analyzed the pharmacological interactions between methylphenidate and methamphetamine in rats at the behavioral level. Instead of finding that methylphenidate alters methamphetamine-induced locomotor activity, it was methamphetamine which modified, potentiated, locomotor activity induced by methylphenidate. Further behavioral and biochemical experiments (including in vivo microdialysis) allowed us to find a key role of serotonin $(5-\mathrm{HT})$ and $5-\mathrm{HT}_{1 \mathrm{~B}}$ receptors in the potentiating effect of methamphetamine on methylphenidate-induced locomotor activity. Furthermore, a $5-\mathrm{HT}_{1 \mathrm{~B}}$ receptor agonist strongly and dose-dependently potentiated the locomotor activation induced by methylphenidate, a finding that merits investigation vis-a-vis its possible implications for the treatment of attention-deficit hyperactivity disorder (ADHD).

\section{MATERIALS AND METHODS}

\section{Animals and Drugs}

Male Sprague-Dawley rats, weighing 300-350 g, were used in all experiments. Animals, housed in groups of two, were maintained in facilities fully accredited by the Association for the Assessment and Accreditation of Laboratory Animal Care; all experimentation was conducted in accordance with the guidelines of the Institutional Care and Use Committee of the Intramural Research Program, National Institute on Drug Abuse. Methylphenidate hydrochloride and fluoxetine were obtained from Sigma (St Louis, MO), (+)-methamphetamine ( $d$-methamphetamine) hydrochloride was from the NIDA Pharmacy (Baltimore, MD), the selective 5- $\mathrm{HT}_{1 \mathrm{~B}}$ receptor antagonist GR 55562 dihydrochloride and the 5$\mathrm{HT}_{1 \mathrm{~B}}$ receptor agonist CP 94253 hydrochloride were from Tocris (Ellisville, $\mathrm{MO}$ ), and the selective $5-\mathrm{HT}_{2 \mathrm{~A}}$ receptor antagonist ritanserin from RBI (Natick, MA). Ritanserin was dissolved in $10 \%$ 2-Hydroxypropyl- $\beta$-cyclodextrin (Sigma) and all the other drugs were dissolved in saline.

\section{Locomotor Activity}

Locomotion was measured as beam crossings in $40 \times 40 \mathrm{~cm}$ open field (AccuScan Instruments, Columbus, $\mathrm{OH}$ ). There were two different experimental designs. In the first group of experiments, rats were habituated to the apparatus for $90 \mathrm{~min}$, then they were given the first intraperitoneal (i.p.) treatment (methylphenidate, $10 \mathrm{mg} / \mathrm{kg}$, methamphetamine, $1 \mathrm{mg} / \mathrm{kg}$, or fluoxetine, $10 \mathrm{mg} / \mathrm{kg}$ ) and after $120 \mathrm{~min}$ they received the second i.p. treatment with either methylphenidate or methamphetamine (the same doses). Some animals were administered 5-HT receptor antagonists (GR $55562,1 \mathrm{mg} / \mathrm{kg}$, i.p. or ritanserin, $2 \mathrm{mg} / \mathrm{kg}$, i.p.) as first treatment simultaneously with methamphetamine or fluoxetine. Locomotion was recorded from the beginning of the habituation period up to $120 \mathrm{~min}$ after the second treatment. In the second group of experiments, rats received different doses of the 5- $\mathrm{HT}_{1 \mathrm{~B}}$ receptor agonist CP 94253 (0, 1,3 , or $10 \mathrm{mg} / \mathrm{kg}$, i.p.) $120 \mathrm{~min}$ after they were introduced in the open field, followed $30 \mathrm{~min}$ later by methylphenidate $(10 \mathrm{mg} / \mathrm{kg}$, i.p.). Some animals were administered the 5$\mathrm{HT}_{1 \mathrm{~B}}$ antagonist GR $55562(1 \mathrm{mg} / \mathrm{kg}$, i.p.) $30 \mathrm{~min}$ before CP 94253 or saline administration. Locomotion was recorded from the beginning of the habituation period up to $120 \mathrm{~min}$ after GR 55562 administration. The statistical analysis used was the 'summary measures' method (Matthews et al, 1990). In the first group of experiments, the average of the locomotor counts accumulated in 10-min periods during the $60 \mathrm{~min}$ after the second i.p. treatment was used as the summary measure. In the second group of experiments, the average of the locomotor counts accumulated in 10-min periods during the $120 \mathrm{~min}$ after CP 94253 administration was used as the summary measure. Non-paired Student's $t$-test or one-way ANOVA, followed by Newman-Keuls test were used for statistical comparisons, using GraphPad Prism 4.0 software (San Diego, CA).

\section{In Vivo Microdialysis}

Concentric microdialysis probes were prepared as described previously (Pontieri et al, 1995). Animals were anesthetized with $3 \mathrm{ml} / \mathrm{kg}$ of Equithesin (4.44 $\mathrm{g}$ of chloral hydrate, $0.972 \mathrm{~g}$ of Na pentobarbital, $2.124 \mathrm{~g}$ of $\mathrm{MgSO}_{4}, 44.4 \mathrm{ml}$ of propylene glycol, $12 \mathrm{ml}$ of ethanol and distilled $\mathrm{H}_{2} \mathrm{O}$ up to $100 \mathrm{ml}$ of final solution; NIDA Pharmacy), and probes were implanted in the shell of the nucleus accumbens (NAc) (one probe/ animal; coordinates with respect to bregma: anterior, + 2.2; lateral, -0.9 ; ventral, -7.4 from the dura). The experiments were performed on freely moving rats $24 \mathrm{~h}$ after probe implantation. Separate experiments, with different animals, were performed for DA and 5-HT measurements. A Ringer solution (in $\mathrm{mM}$ ) of $144 \mathrm{NaCl}, 4.8 \mathrm{KCl}, 1.7 \mathrm{CaCl}_{2}$, and $\mathrm{MgCl}_{2}$ 1.2 was pumped through the dialysis probe at a constant rate of 1 and $0.5 \mu \mathrm{l} / \mathrm{min}$ for $5-\mathrm{HT}$ assay. After a washout period of $90 \mathrm{~min}$, samples were collected at 20- and 30-min intervals to measure DA and 5-HT content, respectively. After 60 min of collecting samples for baseline, the rats were given the fist i.p. treatment (methylphenidate, $10 \mathrm{mg} / \mathrm{kg}$ or methamphetamine, $1 \mathrm{mg} / \mathrm{kg}$ ) and $2 \mathrm{~h}$ later they were given a second i.p. treatment with methylphenidate and samples were collected for another $2 \mathrm{~h}$. At the end of the experiment, rats were killed with an overdose of Equithesin and methylene blue was perfused through the probe. The brain was removed and placed in a $10 \%$ formaldehyde solution, and coronal sections were cut to verify probe location. DA content was measured by reverse high-performance liquid chromatography (HPLC) coupled to an electrochemical detector, as described in detail previously (Pontieri et al, 1995). 5-HT was determined by HPLC coupled to electrochemical detection. The chromatographic system consisted of a CMA/200 refrigerated microinjector (CMA microdialysis, North Chelmsford, MA), a BAS PM-80 pump (BAS, West Lafayette, IN), and a BAS LC-4C amperometric detector. The mobile phase $(0.1 \mathrm{M}$ sodium phosphate, $1.6 \mathrm{mM}$ sodium decanesulfonic acid, $0.8 \mathrm{mM}$ EDTA, $\mathrm{pH}$ 3.9 , and $9 \%$ acetonitrile plus $0.5 \mathrm{ml}$ triethylamine ( $\mathrm{vol} / \mathrm{vol})$ ) was filtered through a $0.22 \mu \mathrm{m}$ nylon filter and degassed by a BAS on-line degasser and pumped through the system at a 
flow rate of $0.45 \mathrm{ml} / \mathrm{min}$. 5 -HT was separated on a BAS C18 column $(100 \times 2.0 \mathrm{~mm} \times 3 \mu \mathrm{m})$ and detected on a glassy carbon working electrode at an oxidation potential of $+800 \mathrm{mV} v s \mathrm{Ag} / \mathrm{AgCl}$. Dialysate $5 \mathrm{HT}$ levels were quantified by external standard curve calibration, using peak area for quantification. All the reagents used for the mobile phase were analytical grade. The limit of detection (which represents three times baseline noise levels) for DA and 5HT was 0.5 and $0.25 \mathrm{nM}$, respectively. DA and 5-HT values were transformed as percentage of basal values (mean of the three values before the drug injection) and transformed values were statistically analyzed. The 'summary measures' method (Matthews et al, 1990) was also used for statistical analysis of the effect of different drugs and drug combinations, using the average of the three values previous to the first drug administration (basal levels) and the average of the values obtained during the first $60 \mathrm{~min}$ after the first or the second i.p. treatment as the summary measures. Bifactorial ANOVA, followed by Newman-Keuls test and non-paired Student's $t$-test were used for statistical comparisons (GraphPad Prism 4.0 software). A non-paired Student's $t$-test was also used to analyze differences in the DA levels obtained from the sample just before the administration of methylphenidate (second drug administration) between animals pretreated with methylphenidate or methamphetamine.

\section{RESULTS}

Effects of Pretreatment with Methamphetamine or Methylphenidate on the Locomotor Activation Induced by Methamphetamine and Methylphenidate

Doses of $1 \mathrm{mg} / \mathrm{kg}$ of methamphetamine and $10 \mathrm{mg} / \mathrm{kg}$ of methylphenidate were used in all the experiments, as there were found to be equipotent doses in their ability to produce locomotor activation in rats in pilot studies. No significant differences in the locomotor activation induced by methamphetamine were observed between the groups that received a previous administration of either methamphetamine or methylphenidate $2 \mathrm{~h}$ before (non-paired Student's $t$-test: $p>0.05 ; n=7$ in both groups) (Figure 1). On the other hand, a significant increase in the locomotor activation induced by methylphenidate was observed in the group that received methamphetamine $2 \mathrm{~h}$ before, compared with the group pretreated with methylphenidate (non-paired Student's $t$-test: $p<0.05 ; n=7$ in both groups) (Figure 2).

Effects of Pretreatment with Methamphetamine or Methylphenidate on the Changes of the Extracellular Concentrations of DA and 5-HT in the NAs Induced by Methylphenidate

In vivo microdialysis experiments were undertaken to examine the mechanism involved in the methamphetamine-induced potentiation of the locomotor activation mediated by methylphenidate. Extracellular concentrations of DA and 5-HT were measured in the NAc during the administration of methamphetamine $(1 \mathrm{mg} / \mathrm{kg})$ and methylphenidate $(10 \mathrm{mg} / \mathrm{kg})$, followed by a second administration of methylphenidate $(10 \mathrm{mg} / \mathrm{kg}) 2 \mathrm{~h}$ later. As previously

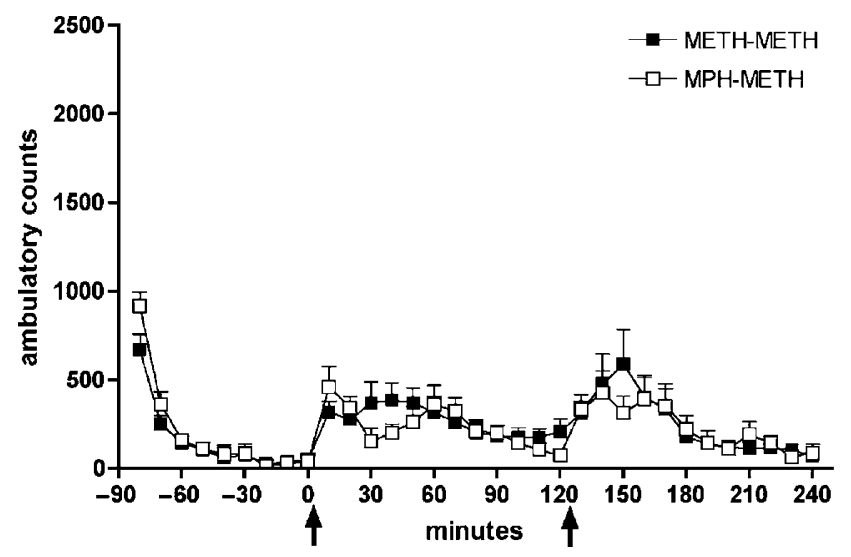

Figure I Effect of pretreatment with methamphetamine (METH; I mg/ $\mathrm{kg}$, i.p.) or methylphenidate (MPH; $10 \mathrm{mg} / \mathrm{kg}$, i.p.) on the locomotor activation induced by METH (I mg/kg, i.p.). Results represent mean \pm SEM of locomotor counts accumulated in 10-min periods. Arrows represent the time of drug administration. No significant differences in locomotor activity (average of the locomotor counts accumulated in 10-min periods during the $60 \mathrm{~min}$ after the second i.p. treatment) were observed between both groups (non-paired Student's t-test: $p>0.05 ; n=7$ in both groups).

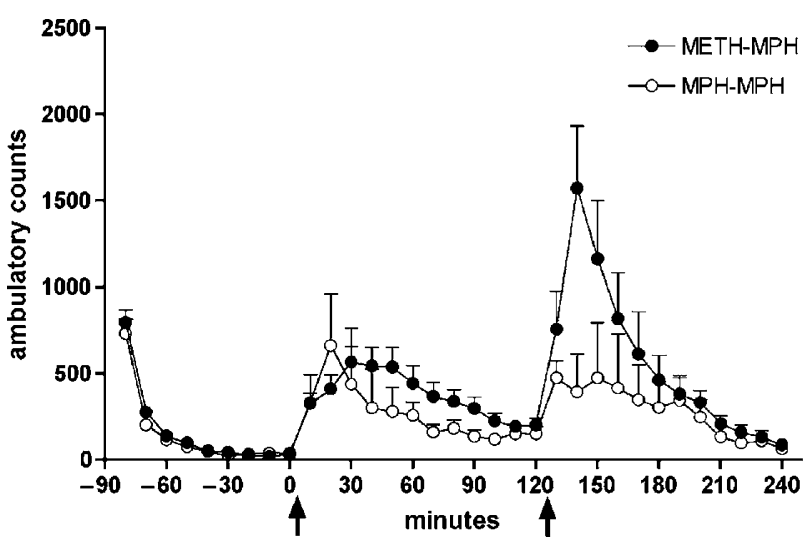

Figure 2 Effect of pretreatment with methamphetamine (METH; I mg/ $\mathrm{kg}$, i.p.) or methylphenidate (MPH; $10 \mathrm{mg} / \mathrm{kg}$, i.p.) on the locomotor activation induced by $\mathrm{MPH}(10 \mathrm{mg} / \mathrm{kg}$, i.p.). Results represent mean \pm SEM of locomotor counts accumulated in 10-min periods. Arrows represent the time of drug administration. A significant increase in locomotor activity (average of the locomotor counts accumulated in 10-min periods during the $60 \mathrm{~min}$ after the second i.p. treatment) was observed in the group that received METH $2 \mathrm{~h}$ before, compared with the group pretreated with MPH (non-paired Student's t-test: $p<0.05 ; n=7$ in both groups).

reported (Kuczenski et al, 1995; Kuczenski and Segal, 1997), immediately after its administration, methamphetamine produced a significant increase in the extracellular concentrations of DA and 5-HT (up to about $400 \%$ of basal levels in both cases; bifactorial ANOVA: $p<0.01$ in both cases; $n=7$ (group), whereas methylphenidate selectively increased DA (up to 500\% of basal levels) without modifying the extracellular concentration of 5-HT (bifactorial ANOVA: $p<0.01$ and $>0.05$, respectively; $n=6-7 /$ group) (Figure $3 \mathrm{a}$ and $\mathrm{b}$ ). The administration of methylphenidate $2 \mathrm{~h}$ after pretreatment with either methylphenidate or methamphetamine produced very similar effects on DA extracellular levels (up to $400-500 \%$ of basal levels; 
bifactorial ANOVA: $p<0.01$ both cases; $n=6-7$ /group) (Figure 3a). Importantly, DA levels just before the administration of methylphenidate in the two groups of animals pretreated with methylphenidate or methamphetamine did not reach basal levels, but they were not statistically different (non-paired Student's $t$-test; $p>0.05 ; n=6-7 /$ group) (Figure 3a). Then, no significant differences in the extracellular levels of DA after methylphenidate administration were observed between the group pretreated with methamphetamine and the group pretreated with methylphenidate (non-paired Student's $t$-test; $p>0.05 ; n=6-7$ / group) (Figure 3a). On the other hand, methamphetamineinduced increases in dialysate 5-HT had not completely fallen to baseline at the time of the second drug (methylphenidate) and the same effect was observed in saline-treated animals pretreated with methamphetamine (up to about $170 \%$ of basal levels; bifactorial ANOVA: $p<0.01 ; n=7$ /group) (Figure $3 \mathrm{c}$ ), which indicates that methamphetamine is responsible for the increased 5-HT levels observed $2-3 \mathrm{~h}$ after its administration and that methylphenidate does not modify this effect.

\section{Effect of Pretreatment with Fluoxetine on the Locomotor Activation Induced by Methylphenidate}

The results from microdialysis experiments suggested that an increase in the extracellular concentration of 5-HT could mediate the methamphetamine-induced potentiation of the locomotor activation induced by methylphenidate. Therefore, we checked if the selective inhibitor of the 5-HT transporter (SERT) fluoxetine could also potentiate the effect of methylphenidate. Fluoxetine $(10 \mathrm{mg} / \mathrm{kg})$, like methamphetamine, was also administered $2 \mathrm{~h}$ before methylphenidate and did not produce any effect on locomotor activity up to $2 \mathrm{~h}$ after its administration, when it significantly potentiated locomotor activation induced by methylphenidate (non-paired Student's $t$-test: $p<0.05$; $n=6-7$ /group) (Figure 4).

\section{Effect of 5-HT Receptor Antagonists on Methamphetamine- and Fluoxetine-Induced Potentiation of Locomotor Activation Induced by Methylphenidate}

Previous studies have indicated that 5-HT can play a permissive or inhibitory role in the motor-activating effects of direct and indirect dopaminergic agonists by acting on different $5-\mathrm{HT}$ receptor subtypes with $5-\mathrm{HT}_{2 \mathrm{~A}}$ and $5-\mathrm{HT}_{1 \mathrm{~B}}$ receptors being stimulatory and $5-\mathrm{HT}_{1 \mathrm{C}}$ being inhibitory (Castanon et al, 2000; Fletcher et al, 2002, 2006; Przegalinski et al, 2002; Bishop and Walker, 2003). Therefore, we investigated the possible ability of the $5-\mathrm{HT}_{2}$ receptor antagonist ritanserin $(2 \mathrm{mg} / \mathrm{kg})$ and the $5-\mathrm{HT}_{1 \mathrm{~B}}$ receptor antagonist GR $55562(1 \mathrm{mg} / \mathrm{kg})$ to counteract methamphetamine- and fluoxetine-induced potentiation of the locomotor activation induced by methylphenidate. GR 55562, but not ritanserin, significantly counteracted the ability of methamphetamine to potentiate locomotor activation induced by methylphenidate (one-way ANOVA: $p<0.05$ and $>0.05$, respectively; $n=7$ /group) (Figure 5). Similarly, GR 55562 , but not ritanserin, significantly counteracted the ability of fluoxetine to potentiate locomotor activation
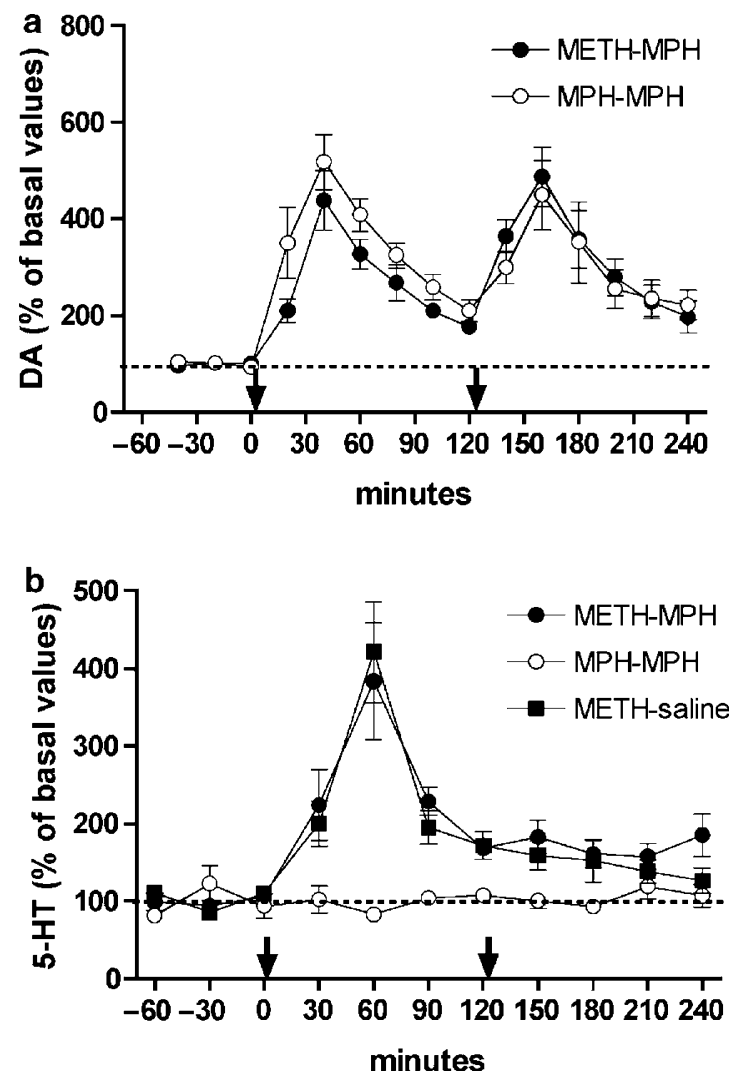

Figure 3 Effect of pretreatment with methamphetamine (METH; I mg/ $\mathrm{kg}$, i.p.) or methylphenidate (MPH; $10 \mathrm{mg} / \mathrm{kg}$, i.p.) on the extracellular levels of DA (a) and $5-H T$ (b) in the NAc induced by $\mathrm{MPH}(10 \mathrm{mg} / \mathrm{kg}$, i.p.). Results represent mean \pm SEM of percentage of basal values. Arrows represent the time of drug administration. The average of the three values previous to the first drug administration (basal levels) and the average of the values obtained during the first $60 \mathrm{~min}$ after the first or the second i.p. treatment were used for statistical comparisons. Immediately after its administration, METH produced a significant increase in the extracellular concentrations of DA and 5-HT (bifactorial ANOVA: $p<0.01$ in all cases; $n=6-7$ /group). Significantly higher $5-\mathrm{HT}$ extracellular levels were still observed $2 \mathrm{~h}$ after METH administration and the same effect was observed in saline-treated animals pretreated with METH (bifactorial ANOVA: $p<0.01 ; n=7$ /group). After the first and second administration, $\mathrm{MPH}$ significantly increased DA (bifactorial ANOVA: $p<0.01$ in both cases; $n=6$ ), but it did not modify $5-\mathrm{HT}$ extracellular levels (bifactorial ANOVA: $p>0.05$ in both cases, $n=7$ ).

induced by methylphenidate (one-way ANOVA: $p<0.05$ and $>0.05$, respectively; $n=6-9 /$ group) (Figure 6).

Effect of the 5-HT 1 Beceptor Agonist CP 94253 on the Locomotor Activation Induced by Methylphenidate

The selective 5- $\mathrm{HT}_{1 \mathrm{~B}}$ receptor agonist CP 94253 (1-10 mg/ $\mathrm{kg}$ ) was administered $30 \mathrm{~min}$ before methylphenidate and did not produce a significant locomotor activation effect on locomotor activity up to $30 \mathrm{~min}$ after its administration, when it very strongly and dose-dependently potentiated locomotor activation induced by methylphenidate. The groups treated with 3 and $10 \mathrm{mg} / \mathrm{kg}$ of CP 94253 plus methylphenidate showed significantly higher locomotor activity compared with the group treated with saline plus methylphenidate (one-way ANOVA, $p<0.05$ and $<0.01$, 


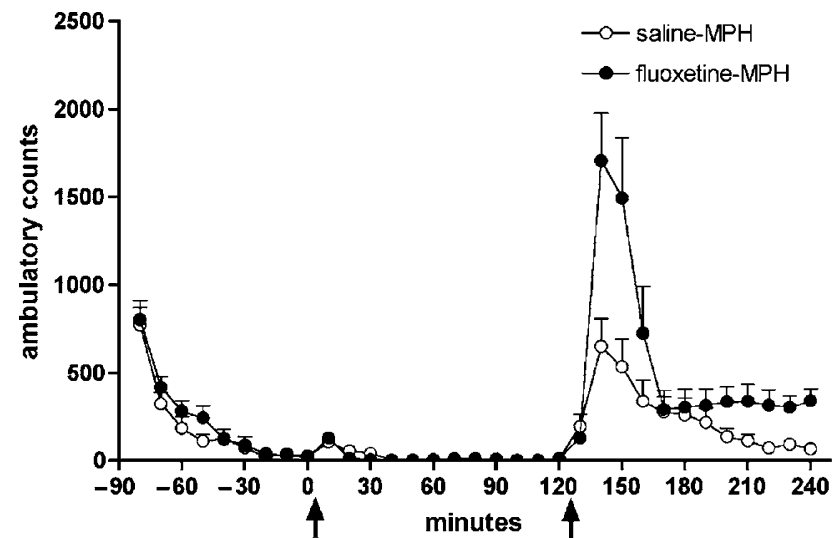

Figure 4 Effect of pretreatment with fluoxetine $(10 \mathrm{mg} / \mathrm{kg}$, i.p.) on the locomotor activation induced by methylphenidate ( $\mathrm{MPH} ; 10 \mathrm{mg} / \mathrm{kg}$, i.p.). Results represent mean \pm SEM of locomotor counts accumulated in 10-min periods. Arrows represent the time of drug administration. A significant increase in locomotor activity (average of the locomotor counts accumulated in 10-min periods during the 60 min after MPH administration) was observed in the group that received fluoxetine $2 \mathrm{~h}$ before, compared with the group pretreated with saline (non-paired Student's t-test: $p<0.05 ; n=6-7$ /group).

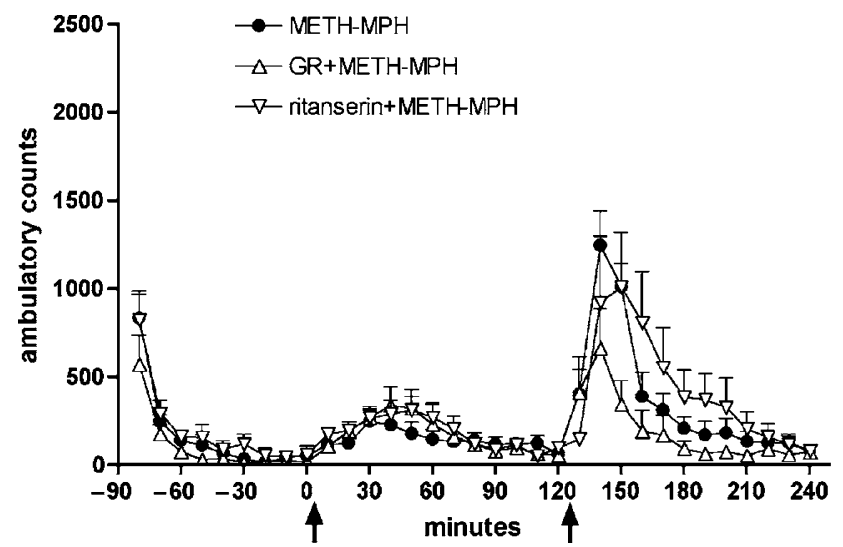

Figure 5 Effect of the $5-\mathrm{HT}_{2}$ receptor antagonist ritanserin $(2 \mathrm{mg} / \mathrm{kg}$, i.p. $)$ and the 5-HT IB receptor antagonist GR 55562 (GR; I mg/kg, i.p.) on the potentiation induced by methamphetamine $(\mathrm{METH}$; I mg/kg, i.p.) of the locomotor activation induced by methylphenidate ( $\mathrm{MPH} ; 10 \mathrm{mg} / \mathrm{kg}$, i.p.). Results represent mean \pm SEM of locomotor counts accumulated in 10-min periods. Arrows represent the time of drug administration. The 5-HT receptor antagonists were given at the time of METH administration. GR, but not ritanserin, significantly counteracted the effect of METH pretreatment on the locomotor activity (average of the locomotor counts accumulated in 10-min periods during the $60 \mathrm{~min}$ after $\mathrm{MPH}$ administration) induced by $\mathrm{MPH}$ (one-way ANOVA: $p<0.05$ and $p>0.05$, respectively; $n=7$ (group).

respectively; $n=5-7 /$ group) (Figure 7). The effect of the treatment with $10 \mathrm{mg} / \mathrm{kg}$ of CP 94253 was significantly counteracted by the previous administration of $1 \mathrm{mg} / \mathrm{kg}$ of the $5-\mathrm{HT}_{1 \mathrm{~B}}$ receptor antagonist GR 55562 (one-way ANOVA, $p<0.05 ; n=7$ /group) (Figure 7 ).

\section{DISCUSSION}

Methylphenidate, an effective and widely used treatment for ADHD (Volkow and Swanson, 2003; Brown et al, 2005), is a

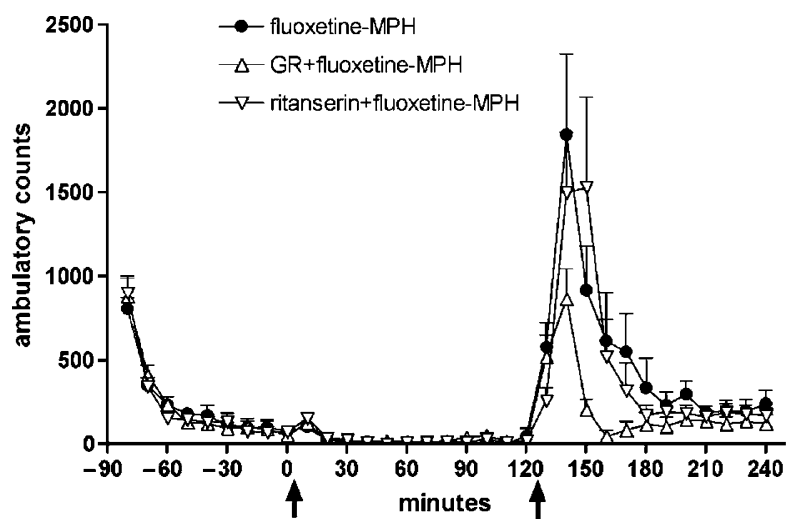

Figure 6 Effect of the $5-\mathrm{HT}_{2}$ receptor antagonist ritanserin $(2 \mathrm{mg} / \mathrm{kg}$, i.p.) and the $5-\mathrm{HT}_{\mathrm{IB}}$ receptor antagonist GR 55562 (GR; I mg/kg, i.p.) on the potentiation induced by fluoxetine- $(10 \mathrm{mg} / \mathrm{kg}$, i.p.) of the locomotor activation induced by methylphenidate (MPH; $10 \mathrm{mg} / \mathrm{kg}$, i.p.). Results represent mean \pm SEM of locomotor counts accumulated in 10-min periods. Arrows represent the time of drug administration. The 5-HT receptor antagonists were given at the time of METH administration. GR, but not ritanserin, significantly counteracted the effect of fluoxetine pretreatment on the locomotor activity (average of the locomotor counts accumulated in 10-min periods during the 60 min after MPH administration) induced by $\mathrm{MPH}$ (one-way ANOVA: $p<0.05$ and $p>0.05$, respectively; $n=6-9 /$ group).

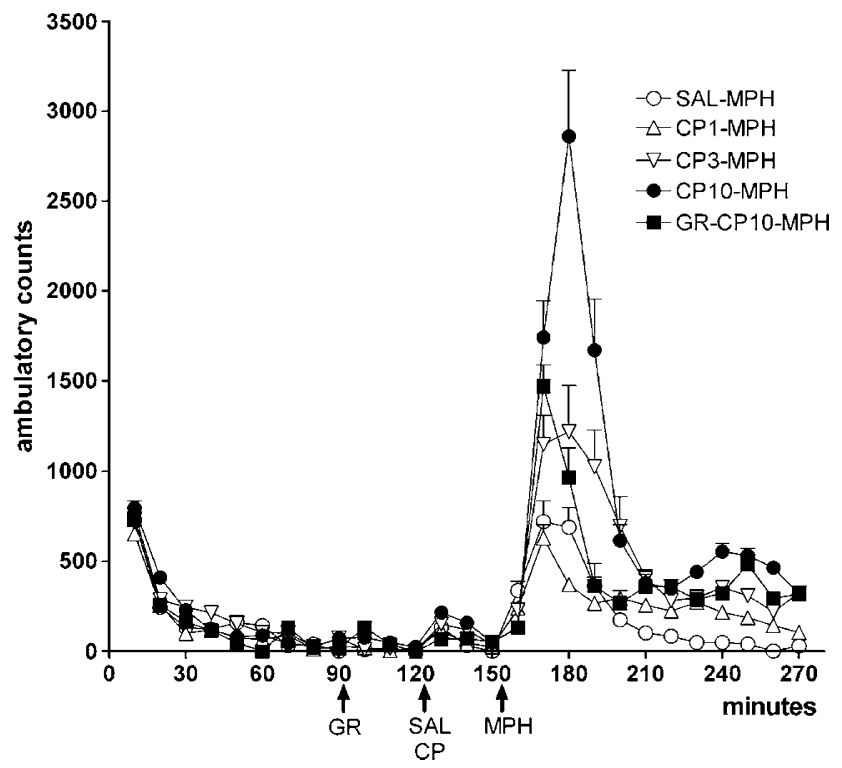

Figure 7 Effect of the 5-HTIB receptor agonist CP 94253 (CPI, CP3, and $\mathrm{CPIO} ; \mathrm{I}, 3$, or $10 \mathrm{mg} / \mathrm{kg}$, i.p., respectively) with or without previous administration of the 5-HT IB receptor antagonist GR 55562 (GR; I mg/kg, i.p.) on the locomotor activation induced by methylphenidate $(\mathrm{MPH}$; $10 \mathrm{mg} / \mathrm{kg}$, i.p.). Results represent mean \pm SEM of locomotor counts accumulated in 10-min periods. Arrows represent the time of indicated drug administration. CP3 and CPIO significantly potentiated locomotor activity (average of the locomotor counts accumulated in 10-min periods during the $120 \mathrm{~min}$ after MPH administration) (one-way ANOVA, $p<0.05$ and $p<0.0$ I, respectively; $n=5-7 /$ group) and the effect of CPIO was significantly counteracted by GR (one-way ANOVA, $p<0.05 ; n=7$ /group). SAL: saline.

psychostimulant with the ability to increase the extracellular concentrations of DA and norepinephrine (NE), but not 5-HT, in the brain (Kuczenski and Segal, 1997). The mechanism of action responsible for the biochemical profile 
of methylphenidate is its ability to interact with DAT and the NE transporter (NET) at much lower concentrations that it interacts with SERT (Han and Gu, 2006). This profile is different to that of cocaine, which binds to DAT, NET, and SERT within a narrow range of concentrations (Han and $\mathrm{Gu}, 2006$ ). However, the previously suggested weaker reinforcing-addictive properties of methylphenidate compared with cocaine do not seem to depend on their differential monoamine uptake inhibitor profile, but on the differences in their pharmacokinetic properties in the brain (Volkow and Swanson, 2003).

The initial aim of the present study was to analyze pharmacological interactions between methylphenidate and the highly abused and neurotoxic psychostimulant methamphetamine (Barr et al, 2006). In our hands, $1 \mathrm{mg} / \mathrm{kg}$ of methamphetamine was equipotent to $10 \mathrm{mg} / \mathrm{kg}$ of methylphenidate at inducing both locomotor activation and DA release in the NAc. When systemically administered within an interval of $2 \mathrm{~h}$, previous administration of methylphenidate did not modify locomotor activation induced by the subsequent administration of methylphenidate or methamphetamine. Similarly, methamphetamine did not significantly modify the motor activation induced by a second administration of the same drug. In contrast, previous administration of methamphetamine markedly potentiated methylphenidate-induced motor activation. It must be pointed out that the behavioral protocol used in the present study is different to that used in studies showing a rapidonset type of behavioral sensitization of psychostimulants, where the effect of a high dose (prime) of a psychostimulant potentiates the behavioral effects of a lower dose (probe) of the same or another psychostimulant (Kuczenski and Segal, 1999a, b; Chinen et al, 2006). Furthermore, at least in rats, this sensitization seems to be restricted to stereotypies, without affecting locomotion (Kuczenski and Segal, 1999a, b).

As previously reported (Kuczenski et al, 1995), methamphetamine was shown to be a very potent 5-HT releaser, whereas methylphenidate did not modify accumbal extracellular 5-HT levels (Kuczenski and Segal, 1997). Methylphenidate produced the same changes in the accumbal extracellular levels of DA after pretreatment with either methylphenidate or methamphetamine, suggesting that methamphetamine-induced potentiation of the locomotor activation induced by methylphenidate is not related to changes in dopaminergic neurotransmission. On the other hand, 5-HT could be involved, as methamphetamineinduced 5-HT release remained significantly elevated for more than $2 \mathrm{~h}$ after its administration. Nevertheless, the differences in motor activity patterns of methylphenidate and methamphetamine cannot be explained solely by their different DA and 5-HT responses. Thus, although the doses of both compounds used in the present study were basically equipotent at inducing locomotor activation and at increasing DA extracellular levels in the NAc, only methamphetamine increased 5-HT levels; but when 5-HT was increased concomitantly with methylphenidate, this resulted in much greater locomotor activation than that observed with methamphetamine. One possible explanation could be a different profile of norepinephrine response. In fact, (+)-methamphetamine (also referred as $d$-methamphetamine, the stereoisomer used in the present study) has been shown to be a poor NE releaser (Kuczenski et al, 1995), whereas methylphenidate is very effective at increasing the extracellular levels of NE in different brain areas (Kuczenski and Segal, 2002; Berridge et al, 2006).

The involvement of 5-HT in the effects of methamphetamine was supported by the results obtained with the SERT blocker fluoxetine, which also potentiated methylphenidateinduced locomotion, in line with previous studies that have shown that fluoxetine enhances the discriminative and motor-activating properties of cocaine (Cunningham and Callahan, 1991; Herges and Taylor, 1998; Bubar et al, 2003). This would imply an additional 5-HT blockade to that induced by cocaine, although it has been suggested that pharmacokinetic effects are involved (Fletcher et al, 2004). Nevertheless, central administration of fluoxetine also potentiates cocaine-induced locomotor activation (Bubar et al, 2003). In any case, in the present study, the effects of both methamphetamine and fluoxetine were selectively counteracted by the $5-\mathrm{HT}_{1 \mathrm{~B}}$ receptor antagonist GR 55562 .

The ability of $5-\mathrm{HT}_{1 \mathrm{~B}}$ receptors to modulate methylphenidate-induced locomotor activation was further analyzed by using the selective $5-\mathrm{HT}_{1 \mathrm{~B}}$ receptor agonist $\mathrm{CP} 94253$ (Koe et al, 1992). In a previous study, high doses of CP 94253 produced locomotor activity in mice (Koe et al, 1992). Within a lower dose range, in the present study, CP 94253 did not produce a significant locomotor activation in rats during the 30 -min period before the administration of methylphenidate, but strongly and dose-dependently potentiated the locomotor activity induced by methylphenidate. As the $5-\mathrm{HT}_{1 \mathrm{~B}}$ receptor antagonist GR 55562 also counteracted the effect of CP 94253, altogether the present results demonstrate that stimulation of $5-\mathrm{HT}_{1 \mathrm{~B}}$ receptors, with either a 5-HT releaser (methamphetamine) or a 5-HT uptake blocker (fluoxetine) or a direct 5-HT agonist (CP 942523), significantly potentiates the locomotor activating effects of the DA uptake blocker methylphenidate. These results might seem in contradiction with previous studies showing that an increased serotoninergic tone counteracts the behavioral, mostly rewarding, effects of the most abused DA uptake blocker cocaine (for a recent review, see Rothman et al, 2006). Also, 5-HT uptake blockers or a direct non-selective 5-HT receptor agonist were reported to enhance the discriminative stimulus properties of the selective DA uptake blocker GBR 12909 (Howell et al, 1997). On the other hand, genetic studies suggest that 5-HT is involved in the rewarding effects of cocaine (Uhl et al, 2002). Nevertheless, when dealing with specific 5-HT receptors, most studies demonstrate a facilitatory role of $5-\mathrm{HT}_{1 \mathrm{~B}}$ receptors on the biochemical, discriminative stimulus, motor, and rewarding effects of cocaine (Callahan and Cunningham, 1997; Lucas et al, 1997; Parsons et al, 1998; Castanon et al, 2000; Filip et al, 2001; Neumaier et al, 2002; Przegalinski et al, 2002; O'Dell and Parsons, 2004). The dampening effects of serotoninergic drugs on the behavioral effects of cocaine or other psychostimulants are most probably related to a predominant stimulation of receptors other than $5-\mathrm{HT}_{1 \mathrm{~B}}$, such as $5-\mathrm{HT}_{2 \mathrm{C}}$ (Fletcher et al, 2002, 2006). Although the reasons why different 5-HT receptor subtypes are predominantly activated under different schedules of administration still need to be determined, $5-\mathrm{HT}_{1 \mathrm{~B}}$ receptors were the main 5 - $\mathrm{HT}$ receptors involved in the results of the present study. 
$5-\mathrm{HT}_{1 \mathrm{~B}}$ receptors are mostly found presynaptically, in nerve terminals of serotoninergic neurons (autoreceptors) and non-serotoninergic neurons (heteroreceptors), and they are highly expressed in the basal ganglia, particularly in the terminals of the GABAergic striatal efferent neurons, that is globus pallidus, ventral pallidum, substantia nigra pars reticulata, and entopeduncular nucleus, where their stimulation inhibits GABA release (Bruinvels et al, 1993; Chadha et al, 2000; Sari, 2004). Therefore, the $5-\mathrm{HT}_{1 \mathrm{~B}}$ receptormediated serotoninergic modulation of methylphenidateinduced locomotor activation demonstrated in the present study most probably involves $5-\mathrm{HT}_{1 \mathrm{~B}}$ receptors localized in the striatal projecting areas. Albeit with lower density, 5$\mathrm{HT}_{1 \mathrm{~B}}$ receptors are also localized in the dorsal and ventral striatum (caudate-putamen and NAc) and in the ventral tegmental area (VTA; Bruinvels et al, 1993; Sari, 2004). In the striatum, they are probably localized in GABAergic terminals, but they are also localized in glutamatergic terminals and their stimulation inhibits striatal glutamatergic neurotransmission (Morikawa et al, 2000). In the VTA, $5-\mathrm{HT}_{1 \mathrm{~B}}$ receptors seem to be localized primarily in the terminals of GABAergic neurons projecting from the NAc and they modulate GABA release (Morikawa et al, 2000; O'Dell and Parsons, 2004). Activation of 5- $\mathrm{HT}_{1 \mathrm{~B}}$ receptors in the VTA, with the consequent disinhibition of dopaminergic cells that project to the NAc, potentiates cocaineinduced increases in NAc DA (O'Dell and Parsons, 2004). However, this mechanism does not seem to be involved in the present results, at least in the potentiating effect of methamphetamine on methylphenidate-induced locomotor activation, as DA release in the NAc induced by methylphenidate was not modified by pretreatment with methamphetamine. On the other hand, striatal 5- $\mathrm{HT}_{1 \mathrm{~B}}$ receptors are probably involved, as the local administration of either a 5$\mathrm{HT}_{1 \mathrm{~B}}$ agonist or the $5-\mathrm{HT}_{1 \mathrm{~B}}$ antagonist GR 55562 in the NAc was shown to potentiate or counteract, respectively, cocaine-induced locomotor activation (Przegalinski et al, 2002). Furthermore, these effects were only observed in the shell of the NAc, the same area where DA and 5-HT were analyzed in the present study (Przegalinski et al, 2002).

In summary, the main finding of the present study is the demonstration of a strong synergistic pharmacological interaction between methylphenidate and a $5-\mathrm{HT}_{1 \mathrm{~B}}$ receptor agonist. The neurophysiological mechanism responsible for this interaction still needs to be determined. It is not known if drugs that enhance the locomotor stimulant effects of methylphenidate in the experimental animal can improve its therapeutic effect in patients with ADHD, but, in view of the widespread use of methylphenidate in ADHD, the study of potential therapeutic benefits of the combination of $5-\mathrm{HT}_{1 \mathrm{~B}}$ receptor agonists with methylphenidate merits investigation. Interestingly, $5-\mathrm{HT}_{1 \mathrm{~B}}$ receptor polymorphisms have been associated with some forms of ADHD (Hawi et al, 2002; Smoller et al, 2006), supporting the hypothesis that $5-\mathrm{HT}_{1 \mathrm{~B}}$ receptors could be a target for the development of drugs active on ADHD.

\section{ACKNOWLEDGEMENTS}

Work supported by National Institute on Drug Abuse intramural research funds.

\section{DISCLOSURE/CONFLICT OF INTEREST}

The author(s) declare that, except for income received from my primary employer, no financial support or compensation has been received from any individual or corporate entity over the past 3 years for research or professional service and there are no personal financial holdings that could be perceived as constituting a potential conflict of interest.

\section{REFERENCES}

Barr AM, Panenka WJ, MacEwan GW, Thornton AE, Lang DJ, Honer WG et al (2006). The need for speed: an update on methamphetamine addiction. J Psychiatry Neurosci 31: 301-313.

Baumann MH, Phillips JM, Ayestas MA, Ali SF, Rice KC, Rothman RB (2002). Preclinical evaluation of GBR12909 decanoate as a long-acting medication for methamphetamine dependence. Ann NY Acad Sci 965: 92-108.

Berridge CW, Devilbiss DM, Andrzejewski ME, Arnsten AF, Kelley $\mathrm{AE}$, Schmeichel B et al (2006). Methylphenidate preferentially increases catecholamine neurotransmission within the prefrontal cortex at low doses that enhance cognitive function. Biol Psychiatry 60: 1111-1120.

Bishop C, Walker PD (2003). Combined intrastriatal dopamine D1 and serotonin 5-HT2 receptor stimulation reveals a mechanism for hyperlocomotion in 6-hydroxydopamine-lesioned rats. Neuroscience 121: 649-657.

Brown RT, Amler RW, Freeman WS, Perrin JM, Stein MT, Feldman HM et al (2005). Treatment of attention-deficit/hyperactivity disorder: overview of the evidence. Pediatrics 5: 749-757.

Bruinvels AT, Palacios JM, Hoyer D (1993). Autoradiographic characterisation and localisation of 5-HT1D compared to 5-HT1B binding sites in rat brain. Naunyn Schmiedebergs Arch Pharmacol 347: 569-582.

Bubar MJ, McMahon LR, De Deurwaerdere P, Spampinato U, Cunningham KA (2003). Selective serotonin reuptake inhibitors enhance cocaine-induced locomotor activity and dopamine release in the nucleus accumbens. Neuropharmacology 44: 342-353.

Callahan PM, Cunningham KA (1997). Modulation of the discriminative stimulus properties of cocaine: comparison of the effects of fluoxetine with 5-HT1A and 5-HT1B receptor agonists. Neuropharmacology 36: 373-381.

Castanon N, Scearce-Levie K, Lucas JJ, Rocha B, Hen R (2000). Modulation of the effects of cocaine by 5-HT1B receptors: a comparison of knockouts and antagonists. Pharmacol Biochem Behav 67: 559-566.

Chadha A, Sur C, Atack J, Duty S (2000). The 5HT(1B) receptor agonist, CP-93129, inhibits [(3)H]-GABA release from rat globus pallidus slices and reverses akinesia following intrapallidal injection in the reserpine-treated rat. $\mathrm{Br} J$ Pharmacol 130: 1927-1932.

Chait LD (1994). Reinforcing and subjective effects of methylphenidate in humans. Behav Pharmacol 5: 281-288.

Chinen CC, Faria RR, Frussa-Filho R (2006). Characterization of the rapid-onset type of behavioral sensitization to amphetamine in mice: role of drug-environment conditioning. Neuropsychopharmacology 31: 151-159.

Cunningham KA, Callahan PM (1991). Monoamine reuptake inhibitors enhance the discriminative state induced by cocaine in the rat. Psychopharmacology 104: 177-180.

Czoty PW, Ramanathan CR, Mutschler NH, Makriyannis A, Bergman J (2004). Drug discrimination in methamphetaminetrained monkeys: effects of monoamine transporter inhibitors. J Pharmacol Exp Ther 311: 720-727. 
Elliott JM, Beveridge TJ (2005). Psychostimulants and monoamine transporters: upsetting the balance. Curr Opin Pharmacol 5: 94-100.

Filip M, Nowak E, Papla I, Przegalinski E (2001). Role of 5-hydroxytryptamine1B receptors and 5-hydroxytryptamine uptake inhibition in the cocaine-evoked discriminative stimulus effects in rats. J Physiol Pharmacol 52: 249-263.

Fletcher PJ, Korth KM, Robinson SR, Baker GB (2002). Multiple 5 -HT receptors are involved in the effects of acute MDMA treatment: studies on locomotor activity and responding for conditioned reinforcement. Psychopharmacology 162: 282-291.

Fletcher PJ, Sinyard J, Higgins GA (2006). The effects of the 5HT(2C) receptor antagonist SB242084 on locomotor activity induced by selective, or mixed, indirect serotonergic and dopaminergic agonists. Psychopharmacology 187: 515-525.

Fletcher PJ, Sinyard J, Salsali M, Baker GB (2004). Fluoxetine, but not sertraline or citalopram, potentiates the locomotor stimulant effect of cocaine: possible pharmacokinetic effects. Psychopharmacology 174: 406-413.

Han DD, Gu HH (2006). Comparison of the monoamine transporters from human and mouse in their sensitivities to psychostimulant drugs. BMC Pharmacol 6: 6.

Hanson GR, Sandoval V, Riddle E, Fleckenstein AE (2004). Psychostimulants and vesicle trafficking: a novel mechanism and therapeutic implications. Ann NY Acad Sci 1025: 146-150.

Hawi Z, Dring M, Kirley A, Foley D, Kent L, Craddock N et al (2002). Serotonergic system and attention deficit hyperactivity disorder (ADHD): a potential susceptibility locus at the $5-\mathrm{HT}(1 \mathrm{~B})$ receptor gene in 273 nuclear families from a multicentre sample. Mol Psychiatry 7: 718-725.

Herges S, Taylor DA (1998). Involvement of serotonin in the modulation of cocaine-induced locomotor activity in the rat. Pharmacol Biochem Behav 59: 595-611.

Holtzman SG (2001). Differential interaction of GBR 12909, a dopamine uptake inhibitor, with cocaine and methamphetamine in rats discriminating cocaine. Psychopharmacology 155: 180-186.

Howell LL, Czoty PW, Byrd LD (1997). Pharmacological interactions between serotonin and dopamine on behavior in the squirrel monkey. Psychopharmacology 131: 40-48.

Hurd YL, Ungerstedt U (1989). $\mathrm{Ca}^{2+}$ dependence of the amphetamine, nomifensine, and $\mathrm{Lu}$ 19-005 effect on in vivo dopamine transmission. Eur J Pharmacol 166: 261-269.

Koe BK, Nielsen JA, Macor JE, Heym J (1992). Biochemical and behavioral studies of the 5-HT1B receptor agonist, CP-94,253. Drug Dev Res 26: 241-250.

Kuczenski R, Segal DS (1997). Effects of methylphenidate on extracellular dopamine, serotonin, and norepinephrine: comparison with amphetamine. J Neurochem 68: 2032-2037.

Kuczenski R, Segal DS (1999a). Sensitization of amphetamineinduced stereotyped behaviors during the acute response. J Pharmacol Exp Ther 288: 699-709.

Kuczenski R, Segal DS (1999b). Dynamic changes in sensitivity occur during the acute response to cocaine and methylphenidate. Psychopharmacology 147: 96-103.

Kuczenski R, Segal DS (2002). Exposure of adolescent rats to oral methylphenidate: preferential effects on extracellular norepinephrine and absence of sensitization and cross-sensitization to methamphetamine. J Neurosci 22: 7264-7271.

Kuczenski R, Segal DS, Cho AK, Melega W (1995). Hippocampus norepinephrine, caudate dopamine and serotonin, and behavioral responses to the stereoisomers of amphetamine and methamphetamine. J Neurosci 15: 1308-1317.

Lucas JJ, Segu L, Hen R (1997). 5-Hydroxytryptamine1B receptors modulate the effect of cocaine on $\mathrm{c}$-fos expression: converging evidence using 5-hydroxytryptamine1B knockout mice and the 5-hydroxytryptamine1B/1D antagonist GR127935. Mol Pharmacol 51: 755-763.

Matthews JN, Altman DG, Campbell MJ, Royston P (1990). Analysis of serial measurements in medical research. BMJ 300: 230-235.

Morikawa H, Manzoni OJ, Crabbe JC, Williams JT (2000). Regulation of central synaptic transmission by $5-\mathrm{HT}$ (1B) autoand heteroreceptors. Mol Pharmacol 58: 1271-1278.

Neumaier JF, Vincow ES, Arvanitogiannis A, Wise RA, Carlezon Jr WA (2002). Elevated expression of 5-HT1B receptors in nucleus accumbens efferents sensitizes animals to cocaine. J Neurosci 22: 10856-10863.

O'Dell LE, Parsons LH (2004). Serotonin1B receptors in the ventral tegmental area modulate cocaine-induced increases in nucleus accumbens dopamine levels. J Pharmacol Exp Ther 311: 711-719.

Parsons LH, Weiss F, Koob GF (1998). Serotonin1B receptor stimulation enhances cocaine reinforcement. J Neurosci 18: 10078-10089.

Pontieri FE, Tanda G, Di Chiara G (1995). Intravenous cocaine, morphine, and amphetamine preferentially increase extracellular dopamine in the 'shell' as compared with the 'core' of the rat nucleus accumbens. Proc Natl Acad Sci USA 92: 12304-12308.

Preti A (2000). Vanorexine national institute on drug abuse. Curr Opin Investig Drugs 1: 241-251.

Przegalinski E, Filip M, Papla I, Czepiel K (2002). Effects of 5-HT1B receptor ligands microinjected into the accumbal shell or core on the cocaine-induced locomotor hyperactivity in rats. J Physiol Pharmacol 53: 383-394.

Rothman RB, Blough BE, Baumann MH (2006). Dual dopamine-5HT releasers: potential treatment agents for cocaine addiction. Trends Pharmacol Sci 27: 612-618.

Sandoval V, Riddle EL, Hanson GR, Fleckenstein AE (2003). Methylphenidate alters vesicular monoamine transport and prevents methamphetamine-induced dopaminergic deficits. J Pharmacol Exp Ther 304: 1181-1187.

Sari Y (2004). Serotonin1B receptors: from protein to physiological function and behavior. Neurosci Biobehav Rev 28: 565-582.

Skjoldager P, Winger G, Woods JH (1993). Analysis of fixed-ratio behavior maintained by drug reinforcers. J Exp Anal Behav 56: 331-343.

Smoller JW, Biederman J, Arbeitman L, Doyle AE, Fagerness J, Perlis RH et al (2006). Association between the 5HT1B receptor gene (HTR1B) and the inattentive subtype of ADHD. Biol Psychiatry 59: 460-467.

Sulzer D, Sonders MS, Poulsen NW, Galli A (2005). Mechanisms of neurotransmitter release by amphetamines: a review. Prog Neurobiol 75: 406-433.

Torres GE, Gainetdinov RR, Caron MG (2003). Plasma membrane monoamine transporters: structure, regulation and function. Nat Rev Neurosci 4: 13-25.

Uhl GR, Hall FS, Sora I (2002). Cocaine, reward, movement and monoamine transporters. Mol Psychiatry 7: 21-26.

Villemagne VL, Wong DF, Yokoi F, Stephane M, Rice KC, Matecka D et al (1999). GBR12909 attenuates amphetamine-induced striatal dopamine release as measured by [(11)C]raclopride continuous infusion PET scans. Synapse 33: 268-273.

Volkow ND, Swanson JM (2003). Variables that affect the clinical use and abuse of methylphenidate in the treatment of ADHD. Am J Psychiatry 160: 1909-1918.

Zetterstrom T, Sharp T, Collin AK, Ungerstedt U (1988). In vivo measurement of extracellular dopamine and DOPAC in rat striatum after various dopamine-releasing drugs; implications for the origin of extracellular DOPAC. Eur J Pharmacol 148: 327-334. 